Vol. 2, No. 1, 2019

Z. O. Znak, R. R. Olenych, O. I. Zin

Lviv Polytechnic National University,

Department of Chemistry and Technology of Inorganic Substances

znak_zo@ukr.net

\title{
STUDY OF THE INTERACTION OF SODIUM TYOCYANATE WITH THE MINERAL ACIDS AND INVESTIGATION OF THE PROPERTIES OF RECEIVED PRODUCTS
}

https://doi.org/10.23939/ctas2019.01.022

It is established that due to the interaction of sodium thiocyanate, which is an admixture in sodium thiosulfate, with mineral acids (nitrate, sulfate, chloride), slightly soluble precipitates are formed. They cause excessive ash content of polymer sulfur, which is obtained by the acid decomposition of sodium thiosulfate. Highly molecular amorphous products are formed in the medium of nitric acid, which are identified as bis (triazine-4,6-dithiol-yl-2) -polysulfide. Under the influence of sulfate and chloride acids are formed low molecular weight products with a high degree of crystallinity, which are well soluble in organic media. The conclusion is made that it is impracticable to extract these products from polymeric sulfur with sodium hydroxide solution because of its possible destruction.

Key words: hydrogen sulfide, sodium thiosulfate, polymer sulfur, sodium thiocyanate, solubility.

3. О. Знак, Р. Р. Оленич, О. І. Зінь

Національний університет “Львівська політехніка", кафедра хімії і технології неорганічних речовин

\section{ДОСЛІДЖЕННЯ ВЗАСМОДІЇ НАТРІЮ ТІОЦІАНАТУ 3 МІНЕРАЛЬНИМИ КИСЛОТАМИ ТА ВИВЧЕННЯ ВЛАСТИВОСТЕЙ ОТРИМАНИХ ПРОДУКТІВ}

\begin{abstract}
Встановлено, що внаслідок взаємодії натрію тіоціанату, який с домішкою у натрію тіосульфаті, з мінеральними кислотами (нітратною, сульфатною, хлоридною) утворюються малорозчинні осади. Вони зумовлюють надмірну зольність полімерної сірки, яку одержують кислотним розкладом натрію тіосульфату. В середовищі нітратної кислоти утворюються високомолекулярні аморфні продукти, які ідентифіковано як біс (триазин-4,6-дитіол-іл-2)полісульфід). Під дією сульфатної та хлоридної кислот утворюються низькомолекулярні продукти 3 високим ступенем кристалічності, добре розчинні в органічних середовищах. Сформульовано висновок про недоцільність вилучення зазначених продуктів 3 полімерної сірки розчинами натрію гідроксиду через її можливу деструкцію.

Ключові слова: сірководень, натрію тіосульфат, полімерна сірка, натрію тіоціанат, розчинність.
\end{abstract}

\section{Introduction}

Hydrogen sulfide gases are formed in many technological processes, in particular, the reprocessing of natural combustible minerals or their purification from Sulfur compounds. The concentration of hydrogen sulfide in these gases, depending on the particular process in which it is formed, varies in a very wide range: from tens of $\mathrm{mg} / \mathrm{m}^{3}$ to almost $100 \%$. Highly concentrated $\mathrm{H}_{2} \mathrm{~S}$ gases produced during the cleaning of oil and natural gas are processed by the Claus method with the production of sulfur $[1,2]$. A very promising method for the processing of such gases is plasmachemical, which enables to obtain not only sulfur, in particular its polymer modification, but also hydrogen - environmentally friendly highcalorie fuel [3, 4]. 
Lowly concentrated gases are traditionally purified by arsenic-sodic [5, 6], quinone [1, 7] (hydroquinone, hypochondria), adsorption and other [8-11] methods. The processes of purifying gases from hydrogen sulfide are complicated by the fact that the components of the absorption solutions pollute the sulfur, which is the main product of the transformation of $\mathrm{H}_{2} \mathrm{~S}$. Therefore, it should be further cleaned further. A serious disadvantage of these purification methods is the formation together with sulfur of by-products primarily thiosulfates, which also require further disposal.

One of the effective methods for the disposal of thiosulphates is their acid decomposition to obtain a polymeric modification of sulfur [12]. It is established that the obtained products are effective agents for the vulcanization of rubber [13].

However, during the treatment of coke oven gas containing theseanads, from hydrogen sulfide using arsenic-sodic method, sodium thiocyanate is formed together with thiosulphate. Polymer sulfur, which is formed as a result of the acid decomposition of sodium thiosulfate, contains insoluble impurities. They reduce the rheological properties of polymer sulfur and cause its excessive high ash content - up to $8 \%$.

Consequently, high-quality polymeric sulfur can be obtained in three ways. The first is to preclean hydrogen sulfide gas from cyanides, which is very difficult to implement technologically at existing plants. The second method is to purify thiosulphate solution from sodium thiocyanate to acid treatment. The third is to purify the product (polymer sulfur) from impurities formed during the interaction of sodium thiocyanate with mineral acids. To do this, you need to know the chemical composition and the main physical and chemical properties of the formed impurities.

Therefore, the purpose of the study was to study the interaction of sodium thiocyanate with mineral acids, as well as study the main properties of the formed products.

\section{Materials and methods of research}

Investigation of the interaction of sodium thiocyanate with concentrated mineral acids was investigated on a laboratory installation, the scheme and description of which is given in [14]. The studies used a NaSCN solution with a concentration of $50 \%$. As acids were used nitrate acid $(57 \%)$, sulfate acid (96\%) and chloride acid $(35 \%)$. These concentrations are the same as in the case of production of polymeric sulfur by the acid decomposition of sodium thiosulfate containing $\mathrm{NaSCN}$ as an impurity.

The research was carried out by the method of potentiometric titration of the NaSCN solution with solutions of the corresponding acids. During the addition of acid solutions, during constant stirring, were fixed changes in $\mathrm{pH}$ values $(\mathrm{pH}-$ meters-millivoltmeter pH-121, electrodes: ESL43-07 (glass), EVL-1M (chloride-silver)) and changes in redox potential ( $\mathrm{pH}$-meter-milivoltmeter pH-673, electrodes: EPL-1 (platinum) EVL-1M (chloride-silver)). Samples of the reaction medium were periodically sampled to measure the optical characteristics of the reaction media using a photocolorimeter KFK-3 in the nephelometry mode $(30 \mathrm{~mm}$ cuvettes, solutions of the corresponding solutions of the corresponding acids). It was believed that the chemical interaction ended when the constancy of all the parameters that were fixed was achieved.

The slightly soluble reaction products in these acidic media were isolated from the mother liquors by filtration on the Shota filter and dried to a constant mass at $50{ }^{\circ} \mathrm{C}$ under vacuum.

Subsequently, the solubility of the obtained products in inorganic and organic media was determined by gravimetric method. The IR spectra of these products in the form of a $15 \%$ suspension in petroleum jelly were taken on a Spectrophotometer "SPECORD M-80 Carl Zeiss Iena" with a single crystal $\mathrm{KBr}$ in the wavelength range of 400$4000 \mathrm{~cm}^{-1}$. The analyzed sample was made as tablets of $\mathrm{KBr}$. Weight of weight gain $-100 \mathrm{mg}$, thickness of the tablet $-3 \mathrm{~mm}$.

Microscopy of the products was carried out using a metallographic microscope with a Kocom Eye KSS-340, which was dial-up from the PC. The Vegas Video 3.0 software was used to capture images and process them.

$\mathrm{X}$-ray diffraction analysis was performed using the DRON-2.0 diffractometer $(\mathrm{Cu} \quad(\mathrm{Ka})$ radiation). The degree of crystallinity of the products was determined by the method of Matthew.

\section{Research results and their discussion}

After adding up to $100 \mathrm{~cm}^{3}$ of $50 \%$ sodium thiocyanate solution a few drops of nitric acid, the 
redox potential of the medium increased sharply from -170 to $+220 \mathrm{mV}$ (Fig. 1). Such a change of the redox-potential of the system is not typical of the typical oxidition-reducing titration. Consequently, it can be assumed that nitric acid plays the role of a non-reactant that interacts with $\mathrm{NaSCN}$, but is a catalyst for the conversion of sodium thiocyanate.

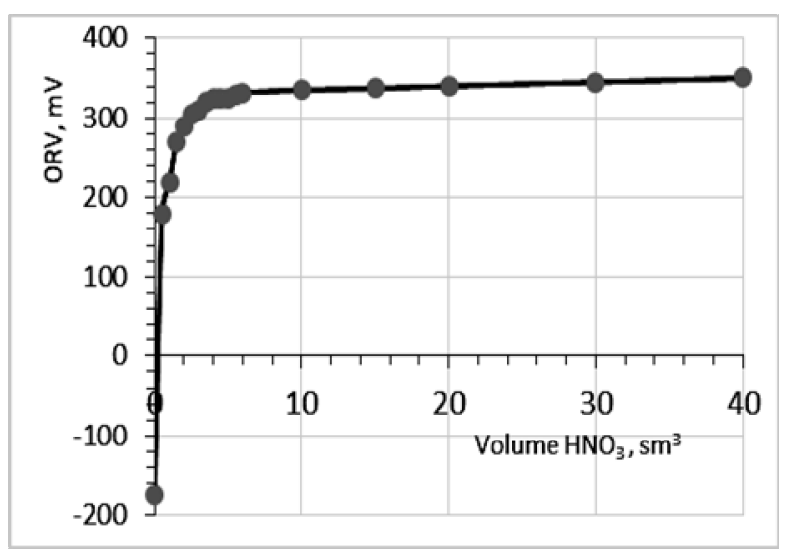

Fig. 1. The dependence of the redox potential of the NaSCN solution from the volume of $\mathrm{HNO}_{3}$

Under the action of $\mathrm{HNO}_{3}$ as a strong oxidant, the $\mathrm{C} \equiv \mathrm{N}$ bond collapses. In this case, the atom of the Nitrogene displaces the electron density on itself, which causes the formation of resonant structures

$$
{ }^{-} \mathrm{S}-\mathrm{C} \equiv \mathrm{N}: \Leftrightarrow{ }^{-} \mathrm{S}-\mathrm{C}^{+}=\mathrm{N}^{-},
$$

that subsequently interact with each other on the nitrogen atom - there is a trimerization of the thiocyanate to form triazine-2,4,6-tritiol

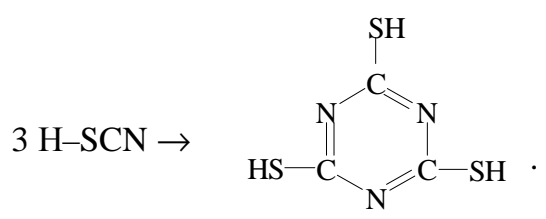

This product was formed in the form of dispersed particles of irregular shape from yellow to orange with sizes up to $1 \mathrm{~mm}$. The probable mechanism of the transformation of $\mathrm{NaSCN}$ in the presence of $\mathrm{HNO}_{3}$ to the formation of insoluble compounds can be proposed based on the analysis of its structure. According to X-ray diffraction data, the $\mathrm{SCN}$-ion is linear and characterized by the parameters $\mathrm{d}(\mathrm{NC})=1.24$ and $\mathrm{d}(\mathrm{CS})=1.58 \AA$; The thermochemical radius $\mathrm{SCN}$-ion equals $1.95 \AA$, which corresponds to the structure $-\mathrm{N}=$ $=\mathrm{C}=\mathrm{S}$, and according to the spectra of the combination scattering of saline molds, the structure $-\mathrm{S}-\mathrm{C} \equiv \mathrm{N}$ is dominant.

Thiocyanate-ion has ambient properties, that is, dual reactivity and, depending on the mechanism of the reaction, forms thiocyanates for the SN2-mechanism or iso-isocyanates by the SN1-mechanism.

This ambiguity is due to the peculiarities of the thiocyanate anion whose resonant structures indicate the possibility of localizing a negative charge both on the Carbon atom and the Nitrogene.

The -SH groups lead to the reduction properties of triazine-2,4,6-tritiol. Therefore, it can interact with $\mathrm{HNO}_{3}$, which dissociate in aqueous solution under a radical mechanism:

$$
\begin{gathered}
\mathrm{HNO}_{3} " \mathrm{HO} \mathrm{HO}^{\bullet}+\mathrm{NO}_{2}^{\bullet}, \\
\mathrm{NO}_{2}{ }^{\bullet} " \mathrm{O}^{\bullet}+\mathrm{NO} .
\end{gathered}
$$

The formed radicals contribute to the oxidation of triazine-2,4,6-tritiol in the -SH group, followed by the formation of dimer - bis (triazine4,6-dithiol-yl-2)-disulphide<smiles>Sc1nc(S)nc(S)n1</smiles><smiles>Sc1nc(S)nc(SSc2nc(S)nc(S)n2)n1</smiles>

On the basis of the performed calculations, the spatial formula bis-(triazine-4,6-dithiol-yl-2)disulphide was proposed (Fig. 2).

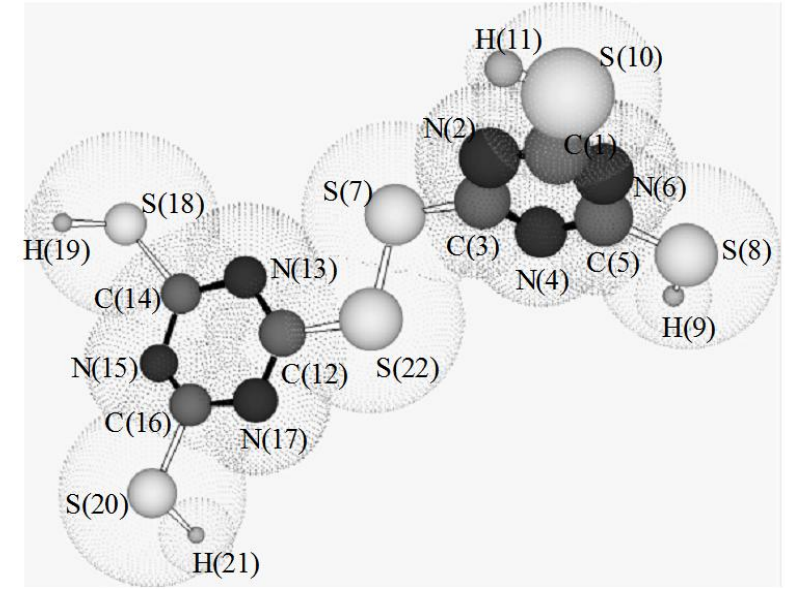

Fig. 2. Spatial appearance of the molecule bis- (triazine-4,6-dithiol-yl-2)-disulphide 
Calculated lengths of bonds in this connection are given in the Table 1 .

Table 1

The length of the bonds in the structure bis- (triazine-4,6-dithiol-yl-2)-disulphide

\begin{tabular}{|c|c|c|c|c|c|}
\hline Bond & $\mathrm{d}, \AA$ & Bond & $\mathrm{d}, \AA$ & Bond & $\mathrm{d}, \AA$ \\
\hline $\mathrm{C}_{1}-\mathrm{N}_{2}$ & 1.358 & $\mathrm{C}_{5}-\mathrm{N}_{6}$ & 1.358 & $\mathrm{C}_{12}-\mathrm{S}_{22}$ & 1.815 \\
\hline $\mathrm{C}_{1}-\mathrm{N}_{6}$ & 1.055 & $\mathrm{C}_{5}-\mathrm{S}_{8}$ & 1.815 & $\mathrm{~N}_{13}-\mathrm{C}_{14}$ & 1.358 \\
\hline $\mathrm{C}_{1}-\mathrm{S}_{10}$ & 1.815 & $\mathrm{~S}_{7}-\mathrm{S}_{22}$ & 2.024 & $\mathrm{C}_{14}-\mathrm{N}_{15}$ & 1.358 \\
\hline $\mathrm{N}_{2}-\mathrm{C}_{3}$ & 1.358 & $\mathrm{~S}_{8}-\mathrm{H}_{9}$ & 1.345 & $\mathrm{C}_{14}-\mathrm{S}_{18}$ & 1.815 \\
\hline $\mathrm{C}_{3}-\mathrm{N}_{4}$ & 1.358 & $\mathrm{~S}_{10}-\mathrm{H}_{11}$ & 1.345 & $\mathrm{~N}_{15}-\mathrm{C}_{16}$ & 1.055 \\
\hline $\mathrm{C}_{3}-\mathrm{S}_{7}$ & 1.815 & $\mathrm{C}_{12}-\mathrm{N}_{13}$ & 1.358 & $\mathrm{C}_{16}-\mathrm{N}_{17}$ & 1.358 \\
\hline $\mathrm{N}_{4}-\mathrm{C}_{5}$ & 1.358 & $\mathrm{C}_{12}-\mathrm{N}_{17}$ & 1.358 & $\mathrm{C}_{16}-\mathrm{S}_{20}$ & 1.815 \\
\hline $\mathrm{S}_{18}-\mathrm{H}_{19}$ & 1.345 & $\mathrm{~S}_{20}-\mathrm{H}_{21}$ & 1.345 & & \\
\hline
\end{tabular}

With excess in the medium $\mathrm{HNO}_{3}$ (at $\mathrm{pH}-1$ and E 360-380 V), bis (triazine-4,6-dithiol-yl-2)polysulfide is formed<smiles>Sc1nc(S)nc(S[As]Sc2nc(S)nc(S)n2)n1</smiles>

The resulting product (Fig. 3) is rather plastic, it is easily agglomerated under the action of mechanical loading, which indirectly indicates its high molecular weight. The X-ray diffraction analysis confirmed that the product obtained is amorphous - no clear reflex was found on the diffractogram; characteristic of crystalline regions; there is only an intense halo.

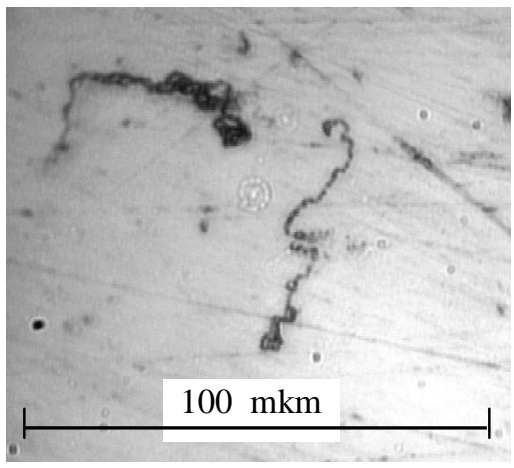

Fig. 3. Photograph of particles of the interaction product of $\mathrm{NaSCN}$ with $\mathrm{HNO}_{3}$

The structure of the product is confirmed by its IR spectrum (Fig. 4, Table 2).

The slight gipsochrome displacement of the absorption region characteristic of the S-S bond is probably due to the influence of the ring structures. During the interaction of $\mathrm{NaSCN}$ with concentrated sulfate and chloride acids at $\mathrm{pH}-1$, compounds are formed, the chemical properties and structure of which are different from those for compounds obtained in $\mathrm{HNO}_{3}$ medium.

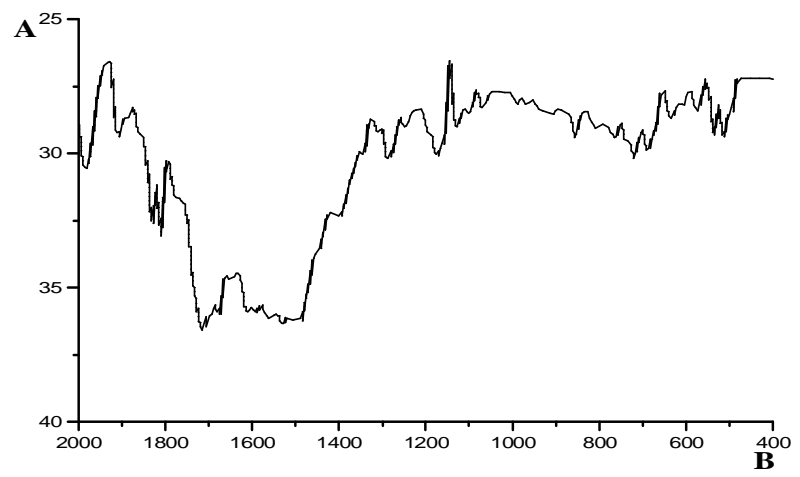

Fig. 4. Infrared spectrum of bis (triazine-4,6-dithiol-yl-2) disulphide: A-absorption; \%, B-frequency, $\mathrm{cm}^{-1}$

Table 2

Characteristic areas of absorption of infrared spectra

\begin{tabular}{|c|c|c|}
\hline $\begin{array}{c}\text { Cycles } \\
\text { and groups }\end{array}$ & $\begin{array}{l}\text { Characteristic } \\
\text { absorption } \\
\text { bands, } \mathrm{cm}^{-1} \\
\end{array}$ & $\begin{array}{c}\text { Detected } \\
\text { absorption } \\
\text { bands, } \mathrm{cm}^{-1}\end{array}$ \\
\hline & $\begin{array}{c}400,675-680, \\
900,1100,1200, \\
1450,1550,1650\end{array}$ & $\begin{array}{c}400,650,920, \\
1090-1100, \\
1110-1240, \\
1430, \\
1490-1510, \\
1610-1650\end{array}$ \\
\hline$-\mathrm{S}-\mathrm{S}-$ & $490-430$ & $500-460$ \\
\hline
\end{tabular}

In particular, the solubility of the products obtained in different solvents is different (Table 3).

Table 3

Solubility of the obtained products in solvents of different nature

\begin{tabular}{|c|c|c|c|c|}
\hline \multirow{2}{*}{ Acid } & \multicolumn{4}{|c|}{ Solubility, g/dm } \\
\cline { 2 - 5 } & Water & NaOH & Toluen & Ethanol \\
\hline $\mathrm{HNO}_{3}$ & 0.02 & 27.32 & 0.04 & 0.06 \\
\hline $\mathrm{H}_{2} \mathrm{SO}_{4}$ & 7.4 & 65.84 & 13.56 & 18.48 \\
\hline $\mathrm{HCl}$ & 10.3 & 29.62 & 16.41 & 22.20 \\
\hline
\end{tabular}

The low solubility of the product obtained in the medium of nitric acid in water and organic solvents can be equivalent to the same type of bonding $\mathrm{C}=\mathrm{N}, \mathrm{C}-\mathrm{N}, \mathrm{C}-\mathrm{S}, \mathrm{S}-\mathrm{H}$ (Table 1).

In the case of the interaction of $\mathrm{NaSCN}$ with sulfate and chloride acids, low molecular weight compounds, in particular triazine-2,4,6-tritiols, which are similar in water and organic solvents, are likely to be formed in most cases. In addition, the degree of crystallinity of both products is high: 
for the obtained action of $\mathrm{H}_{2} \mathrm{SO}_{4}$ it is equal to 8590 , and for the obtained in the medium $\mathrm{HCl}-$ more than $95 \%$. The appearance of both products is similar - they are similar to small crystals (Fig. 5, 6). The different size of crystals is probably due to the change in the concentration of reagents during the reaction.

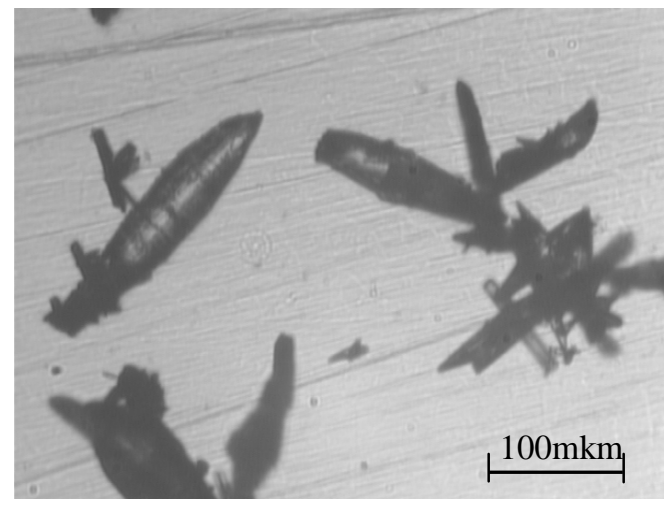

Fig. 5. Photograph of the product of interaction $\mathrm{NSCN}$ of $\mathrm{H}_{2} \mathrm{SO}_{4}$

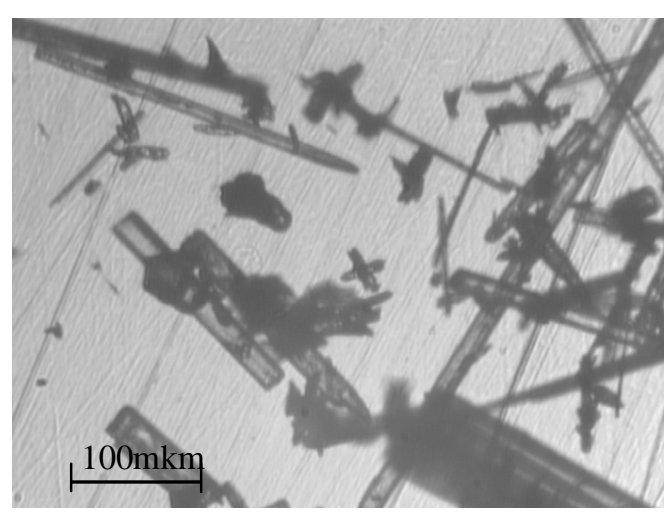

Fig. 6. Photograph of the product of interaction $\mathrm{NSCN}$ with $\mathrm{HCl}$

As can be seen (Fig. 7 and 8), in the medium of $\mathrm{H}_{2} \mathrm{SO}_{4}$ and $\mathrm{HCl}$, products containing similar structural elements and groups, primarily cyclic, are formed. The displacement of reflexes is probably due to the formation of a number of oligomeric compounds under the action of $\mathrm{H}_{2} \mathrm{SO}_{4}$, which although a weaker oxidizer than nitric acid. Therefore, the degree of crystallinity of these products is lower than for $\mathrm{HCl}$.

The high solubility of products obtained in the presence of all acids, in solutions of sodium hydroxide is, in our opinion, two possible reasons. Firstly, by S-S separation by the action of $\mathrm{NaOH}$ that is inherent in polysulfide systems. Secondly, by the substitution of atoms of Hydrogen and Natrium. Both processes cause higher solubility of such compounds in aqueous media.

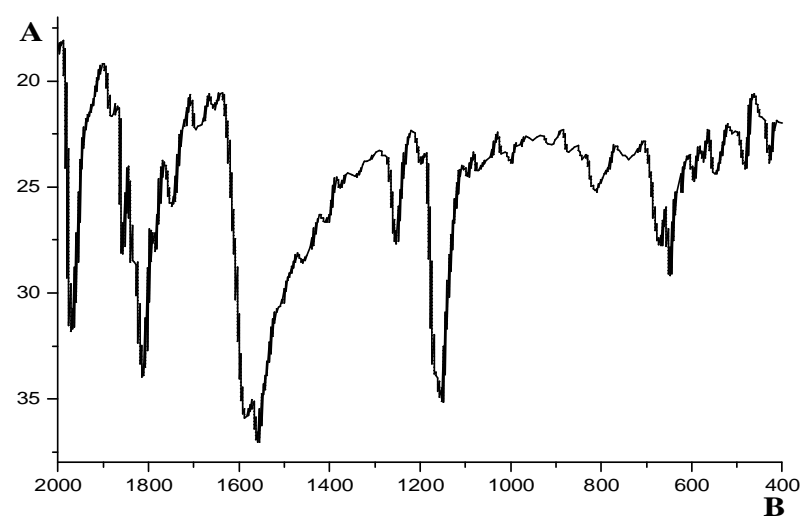

Fig. 7. Infrared spectrum of the product of the interaction of $\mathrm{NaSCN}$ with $\mathrm{H}_{2} \mathrm{SO}_{4}$ :

$A$-absorption, \%; $B$-frequency, $\mathrm{cm}^{-1}$

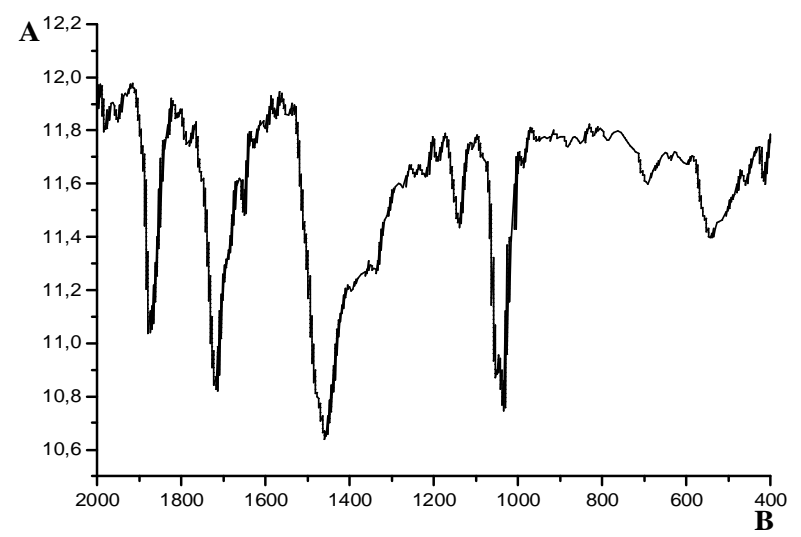

Fig. 8. Infrared spectrum of the product of the interaction of $\mathrm{NaSCN}$ with $\mathrm{HCl}$ :

$A$-absorption, \%; B-frequency, $\mathrm{cm}^{-1}$

The above data show that solutions of $\mathrm{NaOH}$ can be used to purify polymeric sulfur from products of interaction of sodium thiocyanate with acids. However, the destruction of polymer sulfur is possible. It will lead to its transformation into rhombic modification. Therefore, further research will be aimed at the removal of sodium thiocyanate from a solution of sodium thiosulphate before its processing to obtain polymeric sulfur.

\section{Conclusions}

During the interaction of sodium thiocyanate with nitric acid, amorphous, highly soluble products with high molecular weight in organic media are formed. In the case of chloridric acid and nitric acid, low molecular weight products with a high degree of crystallinity are formed which are well soluble in water and organic solvents.

Polymer sulfur, obtained by the acid decomposition of sodium thiosulfate, will be 
contaminated by the products of the interaction of sodium thiocyanate with mineral acids, the removal of which from polymeric sulfur is problematic.

Before acid recycling of sodium thiosulfate, it must be pre-purified from sodium thiocyanate.

\section{References}

1. Kohl, A., \& Nielsen, R. (1997) Gas Purification. - Houston: Gulf Publishing Company.

2. Salisu, I., Ramees, K. R., \& Abhijeet, R. (2017). Roles of hydrogen sulfide concentration and fuel gas injection on aromatics emission from Claus furnace. Chemical Engineering Science, 172, 513-527.

3. Javorsky, V., \& Znak, Z. (2009). Hydrogen sulfide decomposition in ultrahigh-frequency plasma. Chemistry and Chemical Technology. 2(4), 129-131.

4. Мурина, В. И., Кисленко, Н. Н., \& Суркова, Ю. В. (2002). Технологии переработки природного газа и конденсата. Ч. 1. - М.: НедраБизнесцентр.

5. Bannikov, L., Smirnova, A., \& Nesterenko, S. Interpretation of salts influence on the regeneration process of rich thioarsenate solution by oxidativereduction potential measurement. Chemistry and Chemical Technology, 10(1), 67-72.

6. Литвиненко, В. І., Волков, А. И., \& Гонтарь, Н. М. (2001). Процесс мышьяково-содовой очистки коксового газа от сероводорода. Сообщение I. Химизм абсорбции сероводорода УглеХимический журнал, 5-6, 34-39.

7. Yue Dong, Kai Cheng Ling, Wei Shuai Zhang, \& Hua Feng Luo. (2011). Mechanism for the Formation of Elemental Sulfur from Modified Stretford Process. Advanced Materials Research, 1, 892-896.

8. Krischan, J., Makaruk, A., \& Harasek, M. J. (2012). Design and scale-up of an oxidative scrubbing process for the selective removal of hydrogen sulfide from biogas. Journal of Hazardous Materials. 215-216, 49-56.

9. Couvert, A., Charron, I., Laplance, A., Renner, C., Patria, L., \& Requieme, B. (2006). Treatment of odorous sulphur compounds by chemical scrubbing with hydrogen peroxide. Chemical Engineering Science, 61(22), 7240-7248.

10. Рязанцев, А. А., Маликов, Ф. С., Батоева, А. А., \& Фадеенкова, Г. А. (2007). Жидкофазное окисление сероводорода в центробежно-барботажных аппаратах. Журнал прикладной химии. 80(9), 1511-1515.

11. Ter Maat, H., Hogendoorn, J. A., \& Versteeg, G. F. The removal of hydrogen sulfide from gas streams using an aqueous metal sulfate absorbent: Part I. The absorption of hydrogen sulfide in metal sulfate solutions. Separation and Purification Technology, 43(3), 183-197.

12. Знак, 3. О., Оленич, Р. Р., Полулях, О. В., $\&$ Бойко, В. А. (2017). Одержання полімерної сірки із відхідних тіосульфатних розчинів очищення газів від сірководню хінгідронним методом. Вісник Нац. ун-ту “Львівська політехніка". Хімія, технологія речовин та їх застосування, 868, 88-93.

13. Знак, 3. О., \& Оленич, Р. Р. (2016). Фізико-хімічні властивості каучукових композицій, вулканізованих полімерною сіркою. Фізико-хімічна механіка матеріалів, 52(3), 99-104.

14. Знак, 3. О., \& Оленич, Р. Р. (2016). Вплив натрію тіоціанату на утворення i властивості полімерної сірки, отриманої кислотним розкладом натрію тіосульфату. Вісник Нац. ун-ту “Львівська політехніка”. Хімія, технологія речовин та їх застосування, 841, 62-66. 